УДК 793.3+7.072+378(477)

\title{
ДИСЦИПЛІНА «КРИТИКА ХОРЕОГРАФІЇ» В СИСТЕМІ ПІДГОТОВКИ ФАХІВЦЯ ТАНЦЮВАЛЬНОГО МИСТЕЦТВА У ЗАКЛАДАХ ВИЩОЇ ОСВІТИ УКРАЇНИ
}

\author{
Підлипська Аліна Миколаївна, \\ https://orcid.org/0000-0002-7892-337X \\ кандидат мистецтвознавства, доцент, \\ Київський національний університет культури і мистецтв, \\ Київ, Україна, \\ alinaknukim@ukr.net
}

\begin{abstract}
Мета дослідження - обгрунтувати доцільність викладання та запропонувати змістовне наповнення дисципліни «Критика хореографії» в системі підготовки фахівця танцювального мистецтва у закладах вищої освіти України. Методи дослідження. Зважаючи на прикладний характер представленої праці, окрім теоретичного аналізу джерельної бази, систематизації емпіричного матеріалу, проведено концептуалізацію дисципліни «Критика хореографії». Наукова новизна полягає в аналізі сучасного стану танцювальної критики в Україні та світі, окресленні змістовно-тематичного кола дисципліни «Критика хореографії» в системі підготовки фахівця танцювального мистецтва у закладах вищої освіти України. Висновки. Основним завданням танцювальної критики $\epsilon$ пошук адекватних формулювань у вираженні критично-оцінного ставлення до феноменів хореографії сучасності, де алогічна композиційна побудова, нелінійний розвиток сюжету, уникання канонізованої лексики вимагає формування нового критичного лексикону, нових художньо-естетичних орієнтирів в оцінці. В умовах низької вербальної активності практиків хореографічного мистецтва введення дисципліни «Критика хореографії» в систему підготовки фахівців танцювального мистецтва в закладах вищої освіти України може стати одним із дієвих механізмів поглиблення обізнаності у сфері критично-оцінної діяльності. У межах дисципліни раціонально розглянути три тематичні блоки: методологічний (художня критика як естетична категорія, особливості художньо-критичного осмислення феноменів хореографічної культури сучасності), історичний (становлення та розвиток балетної критики у відповідності до основних етапів розвитку балетного театру, європейська, російська та радянська, українська балетознавчі школи), прикладний (розгляд на конкретних прикладах основних форм, об'єктів, жанрів, стилістики та композиції критичних виступів з хореографії, смислових компонентів рецензії, критичної статті.
\end{abstract}

Ключові слова: танщювальна критика; хореографія; критика хореографiї; вища освіта в Україні. 


\title{
ДИСЦИПЛИНА «КРИТИКА ХОРЕОГРАФИИ» В СИСТЕМЕ ПОДГОТОВКИ СПЕЦИАЛИСТА ТАНЦЕВАЛЬНОГО ИСКУССТВА В УЧРЕЖДЕНИЯХ ВЫСШЕГО ОБРАЗОВАНИЯ УКРАИНЫ
}

\author{
Пидлыпская Алина Николаевна, \\ https://orcid.org/0000-0002-7892-337Х \\ кандидат искусствоведения, доцент, \\ Киевский национальный университет культуры и искусств, \\ Киев, Украина, \\ alinaknukim@ukr.net
}

Цель исследования - обосновать целесообразность преподавания и предложить содержательное наполнение дисциплины «Критика хореографии» в системе подготовки специалиста танцевального искусства в учреждениях высшего образования Украины. Методы исследования. Учитывая прикладной характер представленной работы, кроме теоретического анализа источниковой базы, систематизации эмпирического материала, проведено концептуализацию дисциплины «Критика хореографии». Научная новизна заключается в анализе современного состояния танцевальной критики в Украине и мире, очерчивании содержательно-тематического круга дисциплины «Критика хореографии» в системе подготовки специалиста танцевального искусства в учреждениях высшего образования Украины. Выводы. Основной задачей танцевальной критики является поиск адекватных формулировок в выражении критически-оценочного отношения к феноменам хореографии современности, где алогичное композиционное построение, нелинейное развитие сюжета, уход от канонизированной лексики требует формирования нового критического лексикона, новых художественно-эстетических ориентиров в оценке. В условиях низкой вербальной активности практиков хореографического искусства введение дисциплины «Критика хореографии» в систему подготовки специалистов танцевального искусства в учреждениях высшего образования Украины может стать одним из действенных механизмов углубления осведомленности в сфере критически оценочной деятельности. В рамках дисциплины рационально рассмотреть три тематических блока: методологический (художественная критика как эстетическая категория, особенности художественно-критического осмысления феноменов хореографической культуры современности), исторический (становление и развитие балетной критики в соответствии с основными этапами развития балетного театра; европейская, русская и советская, украинская балетоведческие школы), прикладной (рассмотрение на конкретных примерах основных форм, объектов, жанров, стилистики и композиции критических выступлений хореографической тематики, смысловых компонентов рецензии, критической статьи).

Ключевые слова: танцуевальная критика; хореография; критика хореографии; высиее образование в Украине. 


\title{
DISCIPLINE "CRITICISM OF CHOREOGRAPHY" IN THE SYSTEM OF TRAINING OF DANCE ART SPECIALIST IN INSTITUTIONS OF HIGHER EDUCATION IN UKRAINE
}

\author{
Pidlypska Alina \\ https://orcid.org/0000-0002-7892-337X \\ Candidate of Art History, Associate Professor \\ Kiev National University of Culture and Arts, \\ Kyiv, Ukraine, \\ alinaknukim@ukr.net
}

The aim of the study is to justify the appropriateness of teaching and to offer a substantive content of the discipline "Criticism of Choreography" in the system of preparation of dance art specialist in institutions of higher education in Ukraine. Research methods. Taking into account the applied nature of the presented work, in addition to the theoretical analysis of the source base, systematization of empirical material, the discipline "Criticism of Choreography" was conceptualized. The scientific novelty consists in analyzing the current state of dance criticism in Ukraine and the world, outlining the content-thematic circle of the discipline "Criticism of Choreography" in the system of training a specialist in dance art in institutions of higher education in Ukraine. Conclusions. The main task of dance criticism is the search for adequate formulations in the expression of the critically-appraising attitude to the phenomena of modern choreography, where the illogical composition structure, nonlinear development of the plot, the departure from the canonical vocabulary requires the formation of a new critical lexicon, new artistic and aesthetic landmarks in the assessment. In conditions of low verbal activity of practitioners of choreographic art, the introduction of the discipline "Criticism of Choreography" into the system of training dance art specialists in institutions of higher education in Ukraine can become one of the effective mechanisms for deepening awareness in the field of critically evaluated activity. Within the discipline it is rational to consider three thematic blocks: the methodological (artistic critique as an aesthetic category, the features of the artistic critical examination of the phenomena of the choreographic culture of our time), the historical (the development and development of ballet criticism in accordance with the main stages of the development of the ballet theater, Russian and Soviet, Ukrainian ballet schools), application (considering specific examples of basic forms, objects, genres, stylistics and composition of critical performances of the choreographic theme, the semantic components of the review, a critical article).

Key words: dance criticism; choreography; criticism of choreography; higher education.

Актуальність теми дослідження. В Україні та світі в останні роки гостро постали питання танцювальної критики як важливого сегмента хореографічної культури. В сучасних умовах швидкого накопичення мистецьких артефактів саме виявлення ціннісно-смислової сутності хореографічних творів $є$ одним 
3 вагомих чинників культуротворення. В нашій країні катастрофічно бракує фахівців з розумінням специфіки та ролі критики хореографії, орієнтованих не лише на швидкий інформаційно-просвітницький виклад матеріалу, а на аналітику високого гатунку. Введення дисципліни «Критика хореографії» в систему підготовки фахівців танцювального мистецтва в закладах вищої освіти України може стати одним із дієвих механізмів поглиблення обізнаності у сфері критично-оцінної діяльності. Накреслення концептуальних підходів щодо викладання цієї дисципліни є однією з актуальних науково-прикладних проблем, що не потрапляли до кола наукової рефлексії.

Аналіз останніх досліджень і публікацій. Художньо-критичне осмислення різних видів мистецтва та підготовки фахівців для цієї діяльності є одними iз злободенних аспектів вітчизняних наукових розвідок, однак нині можна констатувати недослідженість цих проблем у сфері хореографії, про що свідчить відсутність праць, спеціально присвячених темі. Розмірковуючи над шляхами вкорінення у вітчизняну наукову систему дисципліни «Хореологія», О. Чепалов не оминає і проблем, пов'язаних із хореографічною критикою, зупиняючись на підготовці кадрів («..потребує поліпшення і професійний рівень підготовки балетних критиків, журналістів, які висвітлюють питання хореографічного мистецтва» (Чепалов, 2013, с. 66)), оновленні підходів до сучасних танцювальних феноменів («...критичне осмислення творів сценічного хореографічного мистецтва за новітніми ідейними та художніми критеріями» (Там само, с. 68)).

Певною методологічною основою наукової розвідки із заявленої теми можуть стати монографії О. Петрова (Петров, 1982; Петров, 1995); праця Н. Коршунової (2010) та ін. Динаміку змін у російській балетній критиці кінця XX - початку XXI ст. відзеркалено у збірнику «Нова російська музична критика. 1993-2003. Балет» («Новая русская музыкальная критика...»). Критиці хореографії присвячено різноаспектні дослідження Д. Теодорес (Theodores, 1979), Д. Кемпа (1981), К. Крофт (Croft, 2014) та ін. Проблема підготовки та діяльності критиків хореографії активно обговорюється К. Шваб (Schwab, 2015), К. Лідон (Lydon, 2011) та ін.

У жодній праці не йдеться про набуття компетентностей фахової критичної оцінки феноменів танцювальної культури в системі підготовки кадрів за спеціальністю «хореографія», чим додатково підтверджується актуальність теми статті.

Мета дослідження - обгрунтувати доцільність викладання тазапропонувати змістовне наповнення дисципліни «Критика хореографії» в системі підготовки фахівця танцювального мистецтва у закладах вищої освіти України.

Виклад основного матеріалу. Важливість критики для розвитку будь-якого мистецтва та науки про мистецтво є незаперечним. Критика хореографії є однією з найбільш складних різновидів критичної діяльності, що вимагає досконалого володіння майстерністю вербальної інтерпретації мистецтва іншої, порівняно iз словесною, знакової системи. Проблеми критично-оцінної діяльності у сфері хореографії актуальні упродовж тривалого часу. Наприклад, ще у 1979 р. на сьомій конференції «Танці у Канаді», що відбулася в Торонто (Канада) в Університеті 
Ватерлоо, піднімалися питання професійності та перспектив танцювальної критики. Д. Теодорес висловлювала занепокоєння щодо професійної обізнаності критиків, стверджуючи: «Попри те, що $є$ критики, які можуть написати прекрасну поетичну літературу про танець, без глибокого розуміння сутності танцю та хореографічного ремесла такі тексти не відображають основного напряму розвитку танцювальної критики» (Theodores, 1979). Вона вбачала майбутнє за критиками, які володіють витонченим розумінням танцю разом із глибоким знанням споріднених форм мистецтва. «Дуже важливо, щоб танцювальна спільнота упритул зайнялась завданням виховання перспективних танцювальних критиків, оскільки їхні праці є надзвичайно важливими для всього розвитку танцювального мистецтва», - стверджувала Д. Теодорес (Там само).

І сьогодніпроблеми критичного осмислення сфери хореографіїзалишаються актуальними. Занепокоєння викликає поглинання професійної критики іншими формами оцінних виступів, що знижують загальний рівень пошуку розуміння танцю. Нині, за думкою члена Американської асоціації критиків Р. Беттманна, відбувається «диверсифікація» службових обов'язків критиків танцю, що пов'язане з розміщенням критики у блогах, соціальних мережах тощо (Bettmann, 2017). Такі канали оприлюднення у більшості випадків не передбачають розгорнутої аналітики, вимагають стислості, інформативності, що негативно позначається на загальному рівні критичного осмислення подій хореографічної культури.

Сучасність висуває високі вимоги до підготовки фахівців в системі вищої освіти, що стає запорукою успішної соціалізації, отримання широких можливостей по працевлаштуванню, втілення високих професійних прагнень випускників. Для реалізації мети навчання на другому (магістерському) рівні вищої хореографічної освіти, що прописана у «Стандарті вищої освіти України», а саме «формування у студентів комплексу компетентностей, що забезпечить провадження педагогічної, балетмейстерської, організаційно-управлінської, науково-дослідної діяльності у сфері хореографії» («Стандарт..., с. 3), набуття фахової компетентності «здатність до художньо-критичної діяльності у сфері хореографії» (Там само, с. 6), та досягнення результату навчання - «володіти усними та письмовими навичками художньо-критичного осмислення явищ хореографічної культури сучасності в контексті загальномистецького поступу» (Там само, с. 8) до навчального плану підготовки магістрів за спеціальністю 024 «хореографія» бажано ввести дисципліну «Критика хореографії». Нині у Київському національному університеті культури і мистецтв у межах дисципліни «Хореологія» студенти опановують основні аспекти критично-оцінної діяльності у сфері хореографії. Серед завдань цієї дисципліни - виявити етапи розвитку балетної критики, скласти уявлення про основні форми, об’єкти, жанри хореографічної критики. Широкий спектр завдань, багатий емпіричний матеріал, навички систематизації якого повинні бути сформовані у студентів, необхідність набуття практичних навичок тощо доводить раціональність введення самостійної дисципліни «Критика хореографії».

У межах дисципліни важливо розглянути художню критику як естетичну 
категорію та особливості художньо-критичного осмислення феноменів хореографічної культури сучасності (методологічний розділ у дисципліні «Критика хореографії»). Прослідкувати динаміку змін ролі балетної критики, іiі функціональності у кореляції із соціокультурними змінами є одним із важливих завдань наукового осмислення хореографічного мистецтва в цілому.

Естетика другої половини XX ст. відводила художній критиці вагому суспільну роль: формування думки реципієнта щодо твору мистецтва та особи художника, ба більше- формування його художніх смаків та соціальних орієнтирів, вплив на художника в аспекті коректування його діяльності та ін. (Борев, 1981, с. 128). Нині ситуація змінилась: в умовах зміщення акценту з взаємин художниктвір на твір-реципієнт, повсюдної свободи трактувань, множинності сенсів художнього твору, що виникають саме у процесі сприйняття останнього, на критику вже не покладається обов' язок «маніпулювання» свідомістю суспільства у відповідності до ідеологічних настанов влади, акцент зміщується у бік професійної аналітики, демонстрації авторської позиції рецензента, виявлення широкого спектру розуміння твору.

Однак залишаються незмінними формальні основи балетної критики, яка виникає на основі практики балетного театру, безумовно пов'язана з читацькою та глядацькою аудиторіями, але має вагоме самостійне значення: виявляє, оцінює, аналізує та фіксує тенденції розвитку хореографічного мистецтва. Недарма ж критика $є$ складовою будь-якої мистецтвознавчої дисципліни, включаючи й хореологію.

Головним завданням критики сучасності Н. Коршунова вважає відтворення та збереження «для майбутніх поколінь “образу” показаної вистави, що складається з хореографічного та музичного матеріалу, живописнодекораційного оформлення та індивідуального виконання артистів» (Коршунова, 2010). Актуальність критики як дієвого механізму фіксації образів, що транслює хореографія, нині можна оскаржувати. Від критики хореографії у XXI ст. очікують не стільки «фіксації», скільки фахової критичної «інтерпретації», акцентування на тих аспектах, які критик з авторських позицій вважає художньою цінністю. Також у сучасному комерціалізованому світі від критиків очікують фахового виступу щодо цінності творчості кожного митця, але тут виникають певні загрози необ'єктивності, пов’язані з «монетизацією» думки критика, який виявляється втягнутим у маркетингову систему. І ця проблема потребує окремої уваги.

Сьогоднішнє вільне поводження митців зі структурними хореографічними формами, нелінійний розвиток сюжету у балеті, відхід від суворо класифікованої лексики призвели до пошуку адекватних формулювань у вираженні критичнооцінного ставлення до феноменів сучасної хореографії. Формування нового критичного лексикону, нових художньо-естетичних орієнтирів в оцінці, а скоріше авторській вербальній інтерпретації сучасної хореографічної мови на балетній сцені, балансування між вітіюватою белетристикою та конкретикою фактажу притаманне хореографічній критиці початку XXI ст., яка вже не в змозі спиратися лише на рефлексії класичної хореографії, школа якої була сформована попередніми десятиліттями. 
У наступному («історичному») розділі дисципліни «Хореографічна критика» доцільно розглянути становлення та розвиток балетної критики у відповідності до основних етапів розвитку балетного театру, ознайомитись із європейська балетознавчою школою, приділити увагу становленню та розвитку радянської балетної критики, звернувши увагу на такий її аспект, як ідеологічний тиск (енциклопедичним прикладом балетної критики як засобу ідеологічного тиску стала редакційна стаття «Балетна фальш» у газеті «Правда» (1936), де композитора Д. Шостаковича та балетмейстера Ф. Лопухова, авторів вистави Большого театру «Світлий струмок», було звинувачено у формалізмі, а балет заборонено демонструвати).

Формування балетної критики йшло паралельно 3 професіоналізацією балету. У газетах Франції, Англії, Італії та інших країн оприлюднювали рецензії на балетні вистави критики, чиї імена залишились в історії хореографічного мистецтва (Суриц, Чернова, Петров, 1981). Саме вони стали чи не єдиним джерелом інформації щодо балетмейстерського та виконавського мистецтва певних епох для істориків балету, що не задовольнилися лише сухим фактажем афіш та програмок вистав. Серед визначних критиків балету XVIII-початку XX ст. Ф. Кастиль-Блаза, Т. Готьє у Франції, А. Хаскел у Великобританії, Я. Штелін, М. Яковлєв, І. Бочаров, А. Волинський в Росії. У СРСР значний внесок у розвиток хореографічної критики зробили музикознавці та театрознавці Б. Асафьєв, О. Гвоздев, В. Івінг, А. та М. Гозенпуд, балетознавці Ю. Слонимський, В. Красовська, В. Гаєвський, Н. Аркіна, В. Ванслов, Н. Шереметьєвська та ін.

Вагомою складовою історичного розділу дисципліни «Критика хореографії» повинен стати розгляд проблеми ролі балетної критики в Україні в радянський та пострадянський періоди. Автори одних 3 перших фундаментальних праць 3 історії українського балетного театру Ю. Станішевський (1963), М. Загайкевич (1978) та ін. цитують газетно-журнальні публікації, але не приділяють увагу персоналіям критиків українського балету. Авторами публікацій часто були поети, літератори, композитори, музикознавці та театрознавці: М. Вериківський, М. Вороний, П. Козицький, Я. Полфьоров, М. Шелюбський та ін. У 30-60-ті рр. 3 грунтовними рецензіями на балетні вистави театрів України у всесоюзній та республіканській пресі виступали І. Белза, Я. Ган, А. Гозенпуд, С. Кротевич, М. Рильський, В. Чаговець (Цебенко, 2003). У подальшому публікації Л. Долохової, Ю. Станішевського, М. Загайкевич, Т. Швачко, В. Туркевича, О. Чепалова заклали професійні основи української балетної критики.

До практичного розділу дисципліни «Критика хореографії» (назва «практичний» застосована досить умовно) необхідно внести теми, пов'язані із прикладними аспектами критики. Зокрема, на конкретних прикладах розглянути специфіку основних форм хореографічної критики (газетно-журнальні публікації, теле-радіо- критика, специфічні інтернет-публікації тощо), основні об'єкти критично-оцінної діяльності (твір, учасники процесу, організація тощо), жанри. При розгляді стилістики та композиції критичної публікації з хореографії доцільно торкнутися засобів словесної образності (лексика, епітети, порівняння, метафори), балетознавчих штампів. Необхідно ознайомитись зі смисловими 
компонентами рецензії, критичної статті, а саме: опис об’єкту, формулювання проблеми, аналіз, інтерпретація, оцінка, висновки; також зупинитись на наукових рисах критичного виступу. В якості прикладів доцільно запропонувати публікації хореографічної тематики у вітчизняних журналах «Танець в Україні та світі», «Музика», «Кіно-Театр» та ін., зарубіжних «Dancing Times» (Велика Британія), «Dance Magazine» (США), «Рointe» (США), «Балет» (Росія), «РRO Танец» (Росія) тощо.

Важливим підсумком опанування курсу «Критика хореографії» стане виявлення проблем професійної танцювальної критики та перспектив розвитку критично-оцінної діяльності у сфері хореографічної культури в Україні та світі.

На жаль, в Україні відсутня система підготовки мистецтвознавців 3 хореографічного мистецтва, дуже мало журналістів, хто спеціалізується на цій сфері. Серед тих, хто сьогодні пише журнальні та газетні рецензії та статті про балет і танець, не всі достатньо обізнані в історії вітчизняного балету, не всі розуміють, яке він посідає місце у загальному контексті світового хореографічного мистецтва, і яку роль відіграє хореографічна критика для фахового середовища та суспільства в цілому.

Незважаючи на те, що дисципліна «Критика хореографії» не може ставити за мету підготовку професійних критиків, вважаємо, що набуті компетентності значно підвищать рівень розуміння ролі критично-оцінної діяльності для розвитку хореографічного мистецтва, його популяризації у суспільстві.

Наукова новизна дослідження полягає в аналізі сучасного стану танцювальної критики в Україні та світі, окресленні змістовно-тематичного кола дисципліни «Критика хореографії» в системі підготовки фахівця танцювального мистецтва у закладах вищої освіти України.

Висновки. Основним завданням танцювальної критики є пошук адекватних формулювань у вираженні критично-оцінного ставлення до феноменів хореографіï сучасності, де алогічна композиційна побудова, нелінійний розвиток сюжету, уникання канонізованої лексики вимагає формування нового критичного лексикону, нових художньо-естетичних орієнтирів в оцінці. В умовах низької вербальної активності практиків хореографічного мистецтва введення дисципліни «Критика хореографії» в систему підготовки фахівців танцювального мистецтва в закладах вищої освіти України може стати одним із дієвих механізмів поглиблення обізнаності у сфері критично-оцінної діяльності. У межах дисципліни раціонально розглянути три тематичні блоки: методологічний (художня критика як естетична категорія, особливості художньо-критичного осмислення феноменів хореографічної культури сучасності), історичний (становлення та розвиток балетної критики у відповідності до основних етапів розвитку балетного театру, європейська, російська та радянська, українська балетознавчі школи), прикладний (розгляд на конкретних прикладах основних форм, об'єктів, жанрів, стилістики та композиції критичних виступів з хореографії, смислових компонентів рецензії, критичної статті.

Представлене дослідження не вичерпує всіх аспектів проблеми формування фахівців, обізнаних у сфері танцювальної критики, в процесі підготовки магістрів 
за спеціальністю 024 «хореографія» в закладах вищої освіти України, а лише окреслює основні напрями їі розгляду.

\section{Бібліографічні посилання}

Балетная фальш. Правда. 1936. 6 февраля

Борев Ю. Эстетика. Москва : Издательство политической литературы, 1981.

399 c. URL : http://etika-estetika.ru/books/item/f00/s00/z0000004/st128.shtml

(дата звернення: 2.02.2018).

Загайкевич М. Драматургія балету. Київ : Наукова думка, 1978. 258 с.

Коршунова Н. Русская балетная критика 1910-х годов и творчество A. A. Горского: дис... ученой степени кандидата искусствоведения:

17.00.01 / Государственный институт искусствознания. Москва, 2010. 220

c. URL : http://www.dissercat.com/content/russkaya-baletnaya-kritika-1910kh-godov-i-tvorchestvo-aa-gorskogo\#ixzz5L5Fhp9FU (дата звернення: 7.02.1018).

Кэмп Д. Философские проблемы танцевальной критики. Москва, 1981. 206 с. Новая русская музыкальная критика. 1993-2003. В 3-х т. Т. 2: Балет / сост.

П. Гершензон, А. Рябин, Б. Королек. Москва : Новое литературное обозрение, 2015. 664 с.

Петров О. Русская балетная критика второй половины XIX века. Петербург : монография. Екатеринбург : Сфера, 1995. 415 с.

Петров О. Русская балетная критика кониа XVIII - первой половины XIX века. Москва : Искусство, 1982. 319 с.

Стандарт вищої освіти України. Другий (магістерський рівень). Спеціальність 024 хореографія : проект / Міністерство освіти і науки України. Київ, 2017. URL : https://mon.gov.ua/storage/app/media/vyshcha/naukovo-metodychna rada/proekty_standartiv_VO/024-xoreografiya-magistr-31.10.2017.docx (дата звернення: 27.01.2018).

Станішевський Ю. О. Украӥнський радянський балет. - Київ : Мистецтво, 1963. $-176 \mathrm{c.}$.

Суриц Е., Чернова Н., Петров О. Балетоведение. Балет : энциклопедия / гл. ред.

Ю. Григорович. Москва : Советская энциклопедия, 1981. С. 50-54.

Цебенко I. Балетознавство. Енциклопедія сучасної України. 2003 URL : http:// esu.com.ua/search_articles.php?id=40114 (дата звернення: 24.01.2018).

Чепалов О. Мистецтву танцю - широкі наукові обрії. Культура України, 2013. Вип. 42. С. 62-70.

Bettmann R. The Waning Impact of Dance Critics by Robert Bettmann. 2017. March 1. URL : http://www.dancecritics.org/blog/?p=276 (дата звернення: 22.01.2018).

Croft C. Feminist Dance Criticism and Ballet. 2014. 18 Jun. doi: 10.1080/01472526.2014.915455

Lydon K. Confessions of a Dance Critic. 2011. 16 November. URL : https://www. pointemagazine.com/issuesdecember-2011january-2012 confessions-dancecritic-2412810982.html (дата звернення: 22.01.2018). 
Schwab K. Is Dance Criticism Dead? 2015. 24 August. URL : https://www. dancemagazine.com/is-dance-criticism-dead-2306972115.html (дата звернення: 24.01.2018).

Theodores D. On Critics And Criticism of Dance. 1979. URL : http://sarma.be/ $\mathrm{docs} / 707$ (дата звернення: 22.01.2018).

\section{References}

Baletnaya fal'sh. (1936) [Ballet Feint]. Pravda. February 6 [in Russian].

Borev, Ju. (1981). Estetika [Aesthetics]. Moscow: Izdatel'stvo politicheskoy literatury [Political Literature Publishing House]. Retrieved from http:// etika-estetika.ru/books/item/f00/s00/z0000004/st128.shtml [in Russian].

Zahaikevych, M. (1978). Dramaturhiia baletu [The dramaturgy of Ballet]. Kyiv: Naukova dumka [in Ukrainian].

Korshunova, N. (2010). Russkaya baletnaya kritika 1910-kh godov i tvorchestvo A. A. Gorskogo [Russian ballet criticism of the 1910s and the work of A. A. Gorskij] (dissertation for the degree of Candidate of Art Criticism). Gosudarstvennyj institut iskusstvoznanija [State Institute of Art], Moscow. Retrieved from http://www.dissercat.com/content/russkaya-baletnayakritika-1910-kh-godov-i-tvorchestvo-aa-gorskogo\#ixzz5L5Fhp9FU [in Russian].

Kjemp, D. (1981). Filosofskie problemy tantseval'noy kritiki [Philosophical problems of dance criticism]. Moscow [in Russian].

Novaya russkaya muzykal'naya kritika. 1993-2003 [New Russian musical criticism. 1993-2003]. In 3 volumes. Gershenzon P., Rjabin A. \& Korolek B. (Eds.) Vol. 2: Ballet. Moscow: Novoe literaturnoe obozrenie [New literary review] [in Russian].

Petrov, O. (1995). Russkaya baletnaya kritika vtoroy poloviny XIX veka. Peterburg : monografiya [Russian ballet criticism of the second half of the XIX century. Petersburg: monograph]. Ekaterinburg: Sfera [Sphere] [in Russian].

Petrov, O. (1982). Russkaya baletnaya kritika kontsa XVIII - pervoy poloviny XIX veka [Russian ballet criticism of the late XVIII - first half of the XIX century]. Moscow: Iskusstvo [Art] [in Russian].

Ministry of Education and Science of Ukraine. (2017). Standart vyshchoi osvity Ukrainy. Druhyi (mahisterskyi riven). Spetsialnist 024 khoreohrafia : proekt [The standard of higher education of Ukraine. Second (Master's level). Specialty 024 choreography: project]. Kyiv. Retrieved from https://mon. gov.ua/storage/app/media/vyshcha/naukovo-metodychna_rada/proekty_ standartiv_VO/024-xoreografiya-magistr-31.10.2017.docx [in Russian].

Stanishevskyi, Yu. (1963). Ukrainskyi radianskyi balet [Ukrainian Soviet Ballet]. Kyiv: Mystetstvo Art [in Ukrainian].

Suric, E., Chernova, N. \& Petrov, O. (1981). Baletovedenie [Ballet Studies]. Grigorovich, Ju. (Ed.) Balet: entsiklopediya [Ballet: Encyclopedia]. Moscow: Sovetskaya entsiklopediya [Soviet Encyclopedia], 50-54 [in Russian]. 
Tsebenko, I. (2003). Baletoznavstvo [Ballet Studies]. Entsyklopediia suchasnoi Ukrainy [Encyclopedia of modern Ukraine]. Retrieved from http://esu.com. ua/search_articles.php?id=40114 [in Ukrainian].

Chepalov, O. (2013). Mystetstvu tantsiu - shyroki naukovi obrii [The art of dance wide scientific horizons]. Kultura Ukrainy [Culture of Ukraine], Issue 42, 62-70 [in Ukrainian].

Bettmann, R. (2017). The Waning Impact of Dance Critics by Robert Bettmann. March 1. Retrieved from http://www.dancecritics.org/blog/?p=276 [in English].

Croft, C. (2014) Feminist Dance Criticism and Ballet. Jun 18. doi: 10.1080/01472526.2014.915455 [in English].

Lydon, K. (2011). Confessions of a Dance Critic. November 16. Retrieved from https:// www.pointemagazine.com/issuesdecember-2011january-2012confessionsdance-critic-2412810982.html [in English].

Schwab, K. (2015). Is Dance Criticism Dead? August 24. Retrieved from https://www. dancemagazine.com/is-dance-criticism-dead-2306972115.html [in English].

Theodores, D. (1979). On Critics And Criticism of Dance. Retrieved from http://sarma. be/docs/707 [in English].

(C) Підлипська А. М., 2018

Стаття надійшла до редакиії 12.02.2018 